\title{
Pengembangan Keilmuan Program Studi Manajemen Pendidikan Islam Tinjauan Futurologi Pendidikan dan Pengembangan Kurikulum
}

\author{
Muhammad Amin \\ Institut Agama Islam Negeri (IAIN Curup) \\ dg.m.amin@gmail.com \\ Sugiatno \\ Institut Agama Islam Negeri (IAIN Curup) \\ staincurupsugiatno@gmail.com \\ Irwan Fathurrochman \\ Institut Agama Islam Negeri (IAIN) Curup \\ irwan@iaincurup.ac.id
}

\begin{abstract}
The background of this qualitative research is to look at the Curriculum IAIN as an Islamic Higher Education should have thought about the direction of the development of science in the future, if not then the Curriculum IAIN will be abandoned by both interested people and users, the results of the study indicate that the direction of scientific development of the MPI Study Program Department of Tarbiyah IAIN Curup refers to systemic theo-antrocosmocentric philosophy. The systemic theo-antrocosmocentric paradigm is the work of knowledge which is based on the efforts to attribute, enhance, and accommodate Islamic sciences, social-cultural sciences and science. Making these three families as a chain that cannot be broken which means to combine various elements of knowledge that originate from God and humanity. Deity consists of Islamic sciences including Islamic management. Humanity consists of sociology, culture, communication and science that develops and grows on local wisdom.
\end{abstract}

Key Words : Educational Futurology; Curriculum Development; Islamic Education Management

Abstrak : Latar belakang penelitian kualitatif ini dilakukan adalah mencermati IAIN Curup sebagai Perguruan Tinggi Islam semestinya sudah harus memikirkan arah pengembangan ilmu ke depan, bila tidak maka IAIN Curup akan ditinggalkan baik para peminat maupun para pengguna, hasil penelitian menunjukkan bahwa arah pengembangan keilmuan Program Studi MPI Jurusan Tarbiyah IAIN Curup mengacu pada filosofi teo-antrokosmosentris sistemik. Paradigma teo-antrokosmosentris sistemik adalah kerja pengetahuan yang didasarkan pada upaya mempertalikan, mengingkat, dan mengakomodasi ilmu-ilmu keislaman, ilmu budaya-sosial dan ilmu pengetahuan. Menjadikan tiga rumpun ini sebagai mata rantai yang tak boleh putus yang artinya melakukan penggabungan berbagai unsur pengetahuan yang bersumber dari ketuhanan, dan ke-manusiaan. Ke-tuhanan terdiri dari ilmu-ilmu keislaman termasuk manajemen Islam. Ke-manusiaan terdiri dari ilmu-ilmu sosiologi, budaya, komunikasi dan ilmu yang berkembang dan tumbuh pada kearifan lokal.

Kata Kunci : Futurologi Pendidikan; Pengembangan Kurikulum; Manajemen Pendidikan Islam

TADBIR : Jurnal Studi Manajemen Pendidikan vol. 3, no. 2, November 2019 IAIN Curup - Bengkulu | p-ISSN 2580-3581; e-ISSN 2580-5037 


\section{Pendahuluan}

Perguruan tinggi Islam memiliki peran yang sangat penting dan strategis bagi perkembangan masyarakat dan bangsa. Tingkat kemajuan suatu negara, salah satunya diukur dari tingkat kemajuan perguruan tingginya. Berbagai pemikiran para akademisidi perguruan tinggi sangat berkorelasi dan mempengaruhi perkembangan ekonomi, sosial, politik, maupun aspek kehidupan masyarakat lainnya. Perguruan tinggi berperan sebagai penghasil ilmu pengetahuan dan konsep pemikiran yang berguna bagi kemaslahatan umat manusia. Di perguruan tinggilah iklim akademik ditumbuh suburkan. Disamping itu, perguruan tinggi juga memiliki tanggung jawab dan peran di dalam mempersiapkan anak bangsa menjadi pemimpin yang cerdas dan kritis, namun memiliki moral dan tanggung jawab serta bersikap luhur dalam pengabdiannya kepada masyarakat dan bangsa.

IAIN Curup sebagai lembaga pendidikan Tinggi Islam semestinya sudah harus memikirkan arah pengembangan ilmu ke depan, bila tidak maka IAIN Curup akan ditinggalkan baik para peminat maupun para pengguna. Pengembangan ilmu ke depan itu harus dilandasi oleh kekhasan atau keunikan keilmuan yang dikembangkan dengan melihat sosio-kultural daerah masingmasing.

Pertayaan serupa dapat juga dikemukakan mau dibawa kemana arah pengembangan keilmuan Program Studi Manajemen Pendidikan Islam Jurusan Tarbiyah IAIN Curup? Karena Program Studi Manajemen Pendidikan Islam termasuk program studi yang "unik". Keunikan ini terlihat dari akar dan formasi keilmuannya, sebab disatu sisi berada pada rumpun keilmuan manajemen disisi yang lain berada pada rumpun pendidikan non keguruan. Kondisi ini tentu akan membawa implikasi dan persoalan-persoalan yang mendasar.

Revolusi informasi berdampak luar biasa terhadap reformasi pembelajaran. Dari pembelajaran yang terpusat pada guru menjadi pembelajaran yang berbasis teknologi. Seorang guru dan dosen hanya sebagai fasilitator. Kalau mereka kurang tanggap, siswa dan mahasiswanya dapat meninggalkannya. Pembelajaran juga harus berbasis riset. Seorang guru terutama dosen harus mengajarkan sesuatu berdasarkan hasil riset yang dilakukannya. Dosen tidak boleh hanya mengandalkan pengetahuan "common sense" kepada mahasiswanya.

Dunia sekarang sudah terhubung dengan dunia lain. Meminjam istilah Thomas Friedman bahwa dunia ini "World is flat" dunia sudah datar. Mahasiswa sudah menjadi byperconnected. Mahasiswa sudah terkonek dengan komunitas maya di seluruh dunia. Oleh karenanya, mahasiswa harus dari awal dibekali dengan sejumlah kompetensi dan kesadaran akan global citizenship. Bahwa hidup dan sadar akan komunitas dunia. Penguasaan bahasa asing merupakan keniscayaan untuk memasuki persaingan global. Pertanyaannya kemudian, apakah 
pendidikan tinggi sudah siap dengan situasi ini? Perkembangan ilmu pengetahuan dan penyebarannya juga sudah demikian cepat dan massif.

Selain itu yang juga perlu diperhatikan adalah IAIN Curup yang berada di Kabupaten Rejang Lebong Provinsi Bengkulu dihuni oleh etnis Rejang juga memiliki filosofi yang khas dan dirumuskan dalam satu traktat yang disebut dengan pat sepakat lemo seperno. Artinya Empat Setuju, Lima Sempurna. Konsepsi atau filosofi hidup etnis Rejang ini memiliki kedekatan dengan angka 4 (empat) seperti "empat ajai" dan "empat petula?". Konsepsi ini pada akhirnya menjadi karakter, dan identitas orang-orang Rejang baik dari segi wawasan geopolitik; dan pandangan hidup (world view). Ia juga menjadi penanda dari etnis Rejang yang tersebar di Bengkulu, terutama di Kabupaten Rejang Lebong dimana IAIN Curup eksis dan berkembang.

Bila diselaraskan dengan visi IAIN sesungguhnya telah tergambar arah pengembangan keilmuan IAIN ke depan, yaitu menjadi lembaga pendidikan tinggi Islam yang bermutu, relegius, inovatif dan kompetitif dengan paradigma keilmuan "teo-antrokosmosentris sistemik"(Profil STAIN Curup, 2013).

Paradigma teo-antrokosmosentris sistemik adalah kerja pengetahuan yang didasarkan pada upaya menghubungkan dan mengitegralkan ilmu-ilmu keislaman, ilmu budaya-sosial dan ilmu pengetahuan. Ketiga rumpun ini sebagai mata rantai yang tak terputus satu sama lain karena sebagai simbiosis yang saling bertergantungan. Bila diselaraskan, hal ini sesuai dengan filosofi kultural Rejang bahwa hubungan unsur-unsur yang membentuk kehidupan dan pengetahuan mestilah diikat, dan saling menguatkan, agar tercipta kehidupan yang selaras dan harmonis. Epistemologi ke-Islaman sehingga masing-masing orang, golongan dan aliran sering mengklaim epistemologinya sendiri yang paling benar.

Program Studi Manajemen Pendidikan Islam menyiapkan lulusannya untuk menjadi tenaga kependidikan, yang memiliki kompleksitas dan heterogenitas jenis, sifat dan situasi kelembagaan pendidikan, sehingga upayaupaya pendidikanpun tidak hanya identic dengan guru pada sekolah, melainkan juga system pengelolaan lembaga Islam jalur formal maupun non formal.

Berdasarkan aspek-aspek di atas, maka disiplin ilmu Manajemen Pendidikan Islam dapat dipraktekkan dalam konteks penyelenggaraan satuan pendidikan dari jenjang pendidikan dasar hingga jenjang pendidikan tinggi, pada lembaga atau institusi pemerintahan yang menengani pendidikan pusat maupun daerah dan lemabaga-lembaga pendidikan non formal seperti kursus-kursus, diklat, workshop atau pelatihan lainnya bahkan termasuk majelis taklim.

Dari paparan diatas, maka dilakukan kajian yang mendalam dan konprehensif arah pengembangan keilmuan Program Studi Manajemen Pendidikan Islam Jurusan Tarbiyah yang ada di IAIN Curup dengan pendekatan futurologi pendidikan dan pengembangan kurikulum. Sehingga Program Studi Manajemen Pendidikan Islam dapat eksis dan memiliki peran dalam rangka 
mencetak sumber daya manusia yang responsif, adaptif dan dan dapat bersaing di skala nasional dan internasional.

\section{Kerangka Teori}

\section{1) Futurologi Pendidikan}

Futurologi seringkali disamakan atau dikaitkan dengan istilah-istilah riset masa akan datang (future research), studi masa depan (future studies), riset kebijakan,dan lain-lain. Pada prinsipnya futurologi merupakan kajian tentang kecenderungan-kecenderungan dimasa depan dalam berbagai bidang kehidupan manusia termasuk pendidikan yang mencakup "masa depan yang mungkin terjadi" (possible future), "masa depan yang dapat terjadi" (probable future), dan "masa depan yang diinginkan terjadi" (preferable future), hal ini dikemukakan dalam artikelnya yang mengutip pendapat Rivai (Udik Budi Wibowo dalam Rivai, 1984).

Futurologi adalah ilmu yang mempelajari tentang masa depan, antara lain mempelajari segala prognosa ilmiah tentang situasi dan kondisi masa mendatang di segala bidang, berdasarkan perkembangan situasi masa kini (Van Hoeve; Hassan Shadily, 2019). Dalam pengertian modern, Futorologi ini merupakan usaha untuk mengekstrapolarisasi fakta-fakta yang telah terjadi dan juga perkembangan masa kini dengan pandangan ilmiah yang ketat. Istilah itu baru berkembang di Amerika Serikat dalam masa 10 tahun terakhir dan sekarang ini mulai menjalar ke Eropa (Van Hoeve; Hassan Shadily, 2019).

Futurologi didefinisikan sebagai studi tentang masa depan. Pandangan jauh ke depan yang berusaha untuk menganalisa dan menyoroti asumsi yang mendasari pandangan tersebut. Futurologi adalah bidang interdisipliner mempelajari kemarin dan tema perubahan hari ini, sebagai langkah untuk menggabungkan, menganalisis strategi profesional dan pendapat sehubungan dengan masa depan. Ini mencakup analisis sumber, pola, dan menyebabkan perubahan dan stabilitas dalam upaya untuk mengembangkan pandangan ke depan dan untuk masa depan.

Sejarah kemunculan aliran futurolis bermula seorang filosof terkenal Amarika Serikat Alvin Toffler. Pikiran-pikiran memandang masa depan yang dilontarkannya menjadikan lokomotif dan menciptakan bola salju yang mengelinding semakin besar besar yang kemudian menciptakan asmosfir gerakan futurologis dan maknit yang menyedot perhatian dalam lapisan masyarakat terutama masyarakat industri.

Dalam pandangan gerakan futurologis masyarakat hari ini sudah masuk pada gelombang ke tiga, dimana terjadinya kemajuan teknologi informasi yang mondial dan masif.informasi yang memenuhi ruang hidup masyarakat sekarang ini menandakan bahwa era informasi information age yakni sebutan lain dari gelombang ketiga (the third wave) yang dikemukakan oleh Toffler seorang penulis sekaligus futurolog asal Amerika Serikat. Dalam teorinya, Toffler membagi 
perkembangan peradaban manusia menjadi tiga gelombang, yaitu: gelombang masyarakat agraris (pertanian), gelombang masyarakat industri dan gelombang masyarakat informasi dan sekarang manuasia sudah berada pada gelombang keempat, yaitu gelombang 4.0.

Alvin Toffler dalam bukunya Futuren Shock menjelaskan bahwa gagasangagasan tentang benturan peradaban manusia yang telah menjadi acuan utama para politisi dunia saat itu memompa andrinalinnya dan membuatnya tak mampu menghindarkan diri dari pusaran aktivitas pencarian. Di tengah proses pencarian itulah buku Future Shock hadir di depan publik sebagai bagian dari rangkaian pemikiran Toffler sebelumnya (Alvin Toffler. 1992).

Dengan demikian, dalam pandangan kaum futurology sekarang manusia telah menjalani dua gelombang besar perubahan, yaitu gelombang revolusi agraris dan perubahan cepat yang terjadi pada proses industrialisi. Masingmasing gelombang melenyapkan budaya dan peradaban sebelumnya; dan menggantikannya dengan peradaban baru yang tak dapat dipahami oleh generasi sebelumnya. Revolusi pertanian sebagaimana yang disebutkan Toffler adalah sebagai gelombang pertama yang membutuhkan proses ribuan tahun, sedangkan bangkitnya peradaban indutsri, sebagaimana disebut sebagai gelombang kedua hanya membutuhkan waktu 300 tahun.

Bila dicermati ternyata sejarah berjalan secara lebih akseleratif dalam proses gelombang ketiga yang bakal menyapu bersih bentuk peradaban sebelumnya dan menggantinya dengan sebuah peradaban yang benar-benar baru. Berkaitan dengan itu, konsep dunia masa depan yang disajikan tetap bertumpu pada gagasan-gagasannya terdahulu, khususnya mengenai benturan tiga peradaban manusia. Sejarah manusia merupakan sejarah kehidupan yang paling panjang, proses sejarah manusia melalui tiga fese yaitu masa lalu, kini dan yang akan datang. Ketiga fase tesebut tidak dapat dihindari kecuali hanya dialami oleh manusia itu sendiri.

Dalam teori sistem terdapat 2 konsep yaitu sintropi dan entropi. Dalam hal ini menggunakan konsep sintropi sebagai dasar paradigmatik bagi teori futurologi. Konsep sintropi tersebut biasanya terdapat pada masyarakat yang tertutup, di mana interaksi terjadi hanya di antara komponen sistem dan tidak dengan lingkungan. Para futurolog menciptakan sudut pandang konseptual untuk semua kegiatan yang berorientasi masa depan termasuk pandangan ke depan, futurologi, penelitian berjangka, antisipasi, peramalan, dan lain-lain.

Paradigma dasar futurologi sebagai ilmu masa depan, didasarkan pada saling melengkapinya fenomena entropi dan sintropi di sistem kehidupan. Dapat difahami masyarakat sebagai sistem hidup berkembang dalam peradaban. Dalam hubungan antara teori sistem termasuk pendidikan dengan futurologi dapat dipahami bahwa sebuah sistem memiliki batas-batas yang membedakan 
dari lingkungan dan setiap sistem tersebut merupakan jaringan komunikasi yang membuka aliran informasi untuk proses penyesuaian diri di masa yang akan datang. Pada sistem yang kompleks dimana parameter atau objek merupakan subsistem, hubungan ini adalah perekat yang menghubungkan berbagai subsistem tersebut secara bersama.

Hubungan antara teori sistem dengan futurologi merupakan hubungan yang sinergi dimana semua subsistem yang tidak terikat dioperasikan bersama untuk menghasilkan total output yang lebih besar dibandingkan jika sub-sistem tersebut beroperasi secara sendiri-sendiri untuk mencari solusi yang tepat atas prediksi masalah yang akan terjadi dimasa depan. Pendekatan sistem (sibernetis dan ekuilibrium) sangat bermanfaat untuk menemukan sifat-sifat penting dari sistem yang bersangkutan lalu memberikan keterangan-keterangan kepada kita mengenai perubahan-perubahan apa perlu dilakukan untuk memperbaiki sistem tersebut.

\section{2) Konsep Dasar Futurologis Islam}

Mengingat kajian penelitian ini adalah pengembangan kurikulum pada manajemen pendidikan Islam, maka akan di kemukakan pula konsep dasar futurologis dalam agama Islam. Di ketahui bahwa berkembangnya padangan futurologis optimistik dikalangan umat Islam biasanya didasarkan pada hadits Rasulullah SAW yang diriwayatkan oleh Ahmad yang mengatakan bahwa :

Telab berlaku zaman kenabian ke atas kamu, maka berlakulah zaman kenabian itu sebagaimana yang Allah kehendaki. Kemudian Allah mengangkat zaman itu, dan berlakulah zaman kekhalifahan yang berjalan seperti zaman kenabian. Maka berlakulah zaman itu sebagaimana yang Allab kebendaki. Kemudian Allah mengangkatnya, lalu berlakulah zaman yang menggigit (zaman Fitnah). Berlakulah zaman itu seperti yang Allah kehendaki. Kemudian Allah mengangkatnya pula. Kemudian berlakulah zaman penindasan dan berlakulah zaman itu seperti yang Allab kehendaki. Kemudian berlaku pula zaman kekhalifahan (imam Mabdi) yang berjalan di atas cara bidup zaman kenabian (HR. Ahmad).

Berdasarkan hadits ini memberikan warna optimisme dan menghilangkan pandangan linier pesimistik melalui hadits sebelumnya. Ditambah lagi dengan hadits berikut: "Allah mengutus pada ummat ini di setiap awal seratus tabun orang yang akan memperbarui urusan agamanya (mujaddid)".

Hadits ini memberikan harapan datangnya seorang mujaddid dipangkal setiap abad hijriyah. Dengan demikian setiap satu abad terjadi pembaruan pemikiran Islam. Dinamika pembaruan yang periodik inilah yang memberi warna yang khas pada kesadaran futurologis Islam.

Era kebangkitan dan pencerahan umat Islam tentang pentingnya berpikir ke depan sesungguhnya telah diawali pada abad $15 \mathrm{H}$ yang lalu dengan kesadaran dan kesediaan untuk kembali bersandar pada ajaran Islam sebagai sumber aspirasi maupun rujukan, khususnya di kalangan para pemikir dan 
intelektual muslim yang selama ini lebih berkiblat dengan sains Barat dan mendapatkan pendidikan Barat. Dari merekalah muncul konsep-konsep alternatif di bidang politik, pendidikan, ekonomi dan social budaya.

Bila dicermati sesungguhnya adanya pertalian antara kesandaran futurologist integral Islam dengan pembaharuan umat Islam diberbagai bidang termasuk pendidikan Islam. Hal ini seperti apa yang dikemukakan oleh Azyumardi Azra sebagai berikut:

Gagasan pembaharuan pendidikan Islam, mempunyai akar-akarnya dalam gagasan tentang "modernisme" pemikiran dan institusi Islam secara keseluruhan. Dengan kata lain pembaharuan pendidikan Islam tidak bisa dipisahkan dengan kebangkitan gagasan dan program pembaharuan Islam. Dasar pijakan dari program pembaharuan ini adalah bahwa pembaharuan pemikiran dan kelembagaan Islam merupakan prasyarat bagi kebangkitan kaum Muslimin di era modern. Oleh karena itu, pemikiran dan kelembagaan Islam termasuk pendidikan harus diperbaharui. Mempertahankan pemikiran dan kelembagaan tradisional hanya akan memperpanjang ketidak berdayaan kaum Muslimin dalam menghadapi kemajuan dunia modern (Azyumardi Azra, 1999).

Pembaharuan dalam Islam mengandung adanya trasnformasi nilai yang mesti berubah dan ada kalanya diperlukan perobahan-perobahan terhadap struktur atau tatanan yang sudah ada dan diangap baku. Sedangkan nilai-nilai tersebut tidak mempunyai akar yang kuat berdasarkan sumber-sumber pokok alQur'an dan Hadits. Tanda-tanda perubahan itu terlihat secara transparan, misalnya dari sesuatu yang statis kepada dinamis, dari tradisional ortodok menjadi tradisional ilmiah, dari fanatik menjadi lues dan demokratis (Sani, 2013).

Dari paparan di atas terlihat sangat jelas dari tradisi futuralogis Islam terhadap pembaharuan yang dilakukan oleh umat Islam termasuk pembaharuan dalam bidang pendidikan Islam modern. Tulisan ini akan mengungkap peran tradisi futuralogis Islam terhadap pembaharuan pendidikan Islam modern dengan harapan tulisan ini dapat menjadi inspirasi untuk melakukan kajian yang lebih mendalam.

Dalam pandangan Islam futurologis adalah filsafat Islam modern berdasarkan kepada ayat-ayat al-Qur'an dan ayat ayat alamiah untuk memahami Islam secara baru sehingga dapat digunakan memecahkan permasalahanpermasalahan yang dihadapi oleh umat Islam dewasa ini. Salah satu pandangan baru yang disumbangkan futurologis adalah pencerahan kembali kerangka tujuan hidup manusia, baik diri pribadi maupun sebagai kelompok masyarakat atau umat. Sebagai pribadi tujuan muslim adalah menjadi hamba Allah yang terbaik. Sebagai umat tujuannya adalah dapat membangun peradaban Islam dan menjadi wakil Allah dalam menyebarkan rahmat-Nya di alam semesta. Secara rasional dapat dikatakan bahwa kesadaran futurologis Islam di permulaan perkembangannya justru bersifat linier pesimintik. Pandangan linier pesimistik 
ini dibentuk oleh hadits yang diriwayatkan oleh Bukhari yang mengatakan: "Sebaik-baik kurun adalah kurunku, kemudian kurun berikutnya dan kemudian kurun sesudahnya" (Armahedi Mazhar, 1983).

Di samping berkembang padangan futurologis, dikalangan umat Islam berkembang juga pandangan linier pesimistik lawan dari pandangan futurologi sejak masa pasca sahabat yang diwakili oleh kelompok Jabariah yang berpandangan predeterministik terhadap qadha dan qadar dan ini kemudian menjadi polemik teologis-metafisik dengan kelompok Qodariyah-Mu'tazilah yang mengedapankan akal sebagai faktor intervensi yang memungkinkan dikendalikannya destini masa depan dari setiap individu menurut kehendak mereka. Meskipun Qodariah-Mu'tazilah berpandangan sangat liberal dan sampai kepada kelompok Neo-Mu'tazilah sekarang ini tidaklah tujuan mereka menggingkari adanya kekuatan qodha dan qodar dari Sang Pencipta dan Sang Pengendali, seperti yang dilakukan oleh para pemikir Barat.

\section{3) Ruang Lingkup Futurologi Pendidikan}

Dari pemikiran para pakar dinyatakan bahwa wilayah kajian futurologi mencakup berbagai kajian yang bersifat optimis maupun pesimis dari masa depan dalam berbagai bidang antara lain:demografi, ekologi, ekonomi, energi, kemanusiaan, proses sosial-politik, pendidikan, dan teknologi. Pada dasarnya wilayah kajian futurologi di tingkat global tersebut juga menjadi wilayah kajian futurologi di Indonesia, karena Indonesia merupakan bagian dari masyarakat global (Udik Budi Wibowo, 2015).

Selanjutnya apabila ditilik secara spesifik berkenaan dengan futurologi pendidikan di Indonesia, dapat meminjam pendapat Tilaar yang mengemukakan bahwa dalam mewujudkan masyarakat Indonesia baru, terdapat beberapa tantangan internal yakni: (1) masalah kesatuan bangsa, (2) demokratisasi pendidikan, (3) desentralisasi manajemen pendidikan, dan (4) kualitas pendidikan; dan tantangan eksternal yakni pendidikan yang kompetitif dan inovatif dalam kehidupan global, dan kebudayaan internasional dengan segala aspek positif dan negatifnya (Tilaar. H. A. R. 2000).

Dari pendapat di atas dapat disimpulkan bahwa futurologi pendidikan di Indonesia berhadapan dengan tantangan internal dan eksternal dari sistem pendidikan nasional. Tantangan internal terkait dengan praksis pendidikan dan pengelolaan yang dapat menghasilkan pendidikan yang berkualitas. Sedangkan tantangan eksternal terkait dengan kemampuan menyediakan sumber daya manusia yang unggul untuk dapat berkompetisi dengan bangsa-bangsa lain dalam tata pergaulan global.

\section{4) Pendidikan Masa Depan}

Mengingat telah terjadinya perubahn-perubahan yang sangat pesat akhirakhir ini dimana perubahan tersebut dapat diindentifikasi empat bentuk, yaitu berlangsung cepat, menyeluruh, mendalam, dan serba tidak terduga. Pertama, 
Perubahan berlangsung cepat, karena perubahan tersebut tidak pernah dapat diikuti oleh mereka yang turut terlibat, apalagi oleh mereka yang tidak pernah terlibat. Kedua, Perubahan berlangsung menyeluruh, karena perubahan tersebut menyangkut hampir segala aspek kehidupan dan sektor di dunia ini. Ketiga, Perubahan berlangsung secara mendalam, karena perubahan tersebut sampai ke detail-detail subjek yang sedang atau lagi berubah. Keempat, Perubahan terjadi serba tidak terduga, karena perubahan tidak dapat diestimasi dan diramalkan secara jitu oleh para ahli ramal di berbagai bidang, biarpun hal tersebut dilakukan dengan menggunakan berbagai pendekatan.

Menurut Ali Imron perubahan-perubahan dahsyat yang terjadi di dunia di era belakangan ini dapat dikemukakan sebagai berikut :

a) Globalisasi ekonomi dunia yang pada masa-masa sebelumnya berpusat dikawasan negara-negara sekitar Atlantik berubah kenegara-negara sekitar kawasan Asia Pasifik. Karena kawasan Asia Fasifik menjadi periode perluasan ekonomi yang paling cepat dalam sejarah, pertumbuhannya lima kali kecepatan pertumbuhan selama revolusi industri. Sedangkan negara-negara yang berani melakukan investasi besar dibidang pendidikan, maka akan menjadi paling kompetitif. Di tepi Pasifik, dimana pertumbuhan ekonomi lebih pesat dibandingkan ekonomi Barat yang lebih matang, maka menciptakan adanya kebutuhan akan orang-orang yang berpendidikan baik sangat luar biasa.

b) Perkembangan IPTEK yang semakin pesat : Perkembangan IPTEK yang demikian pesat, justru dimulai bukan dari dunia pendidikan melainkan berasal dari luar dunia pendidikan. Ada yang menyebut era perkembangan IPTEK yang pesat seperti ini sebagai era revolusi industri gelombang ketiga. Revolusi ini meliputi bidang bioteknologi, teknologi bahan, mikro elektronika dan informatika. Akibatnya, negara-negara yang dapat memanfaatkannya semakin eksis dalam percaturan internasional, sementara negara yang tidak dapat memanfaatkan semakin tertinggal bahkan tersisih. Oleh karena itu, antara negara satu dengan negara yang lain saling memperebutkan supremasi di bidang ini. Lambat laun, negara-negara yang kalah akan semakin kehilangan kemampuan dipasar internasional, dan akhirnya akan kehilangan otonominya sebagai negara merdeka.

c) Di bidang demografi, dinyatakan bahwa kian lama jumlah penduduk dunia kian banyak, dan secara umum berada di negara-negara berkembang.Jika penduduk pada negara-negara dunia maju umumnya tinggi tingkat produktivitasnya, maka di negara-negara berkembang sebagian besar justru rendah tingkat produktivitasnya. Oleh karena itu, besarnya jumlah penduduk di negara-negara berkembang umumnya dirasakan sebagai beban. Rendahnya daya saing penduduk negara 
berkembang diberbagai bidang, baik dari segi kemampuan profesionalnya, ketahanan fisiknya, keuletannya bekerja, serta kecepatan kerjanya, akan senantiasa menempatkan posisi negara-negara berkembang pada posisi marginal.

d) Pada negara-negara berkembang, umumnya mengirimkan tenaga buruh dengan upah rendah ke negara-negara maju, sementara negara-negara maju justru mengekspor tenaga ahlinya dengan bayaran yang tinggi ke negara-negara berkembang. Terdapat hubungan kerja yang tidak seimbang di bidang ini, oleh karena satu orang tenaga ahli di bidangnya, harus ditukar dengan sekian banyak jumlah tenaga buruh kasar. Oleh karena itu, kebijakan pendidikanlah yang dapat mengulurkan tangan serta mewujudkan terciptanya manusia yang unggul dari banyak segi. Hal ini sangat berarti bagi penyiapan negara agar dapat menempatkan diri di percaturan dunia (Imron, 2012).

Sekolah sebagai institusi tempat masyarakat berharap, dituntut untuk melakukan perubahan dan perbaikan guna mencapai pendidikan bermutu sebagaimana yang diharapkan masyarakat tersebut. Perubahan dan perbaikan pendidikan dapat tercapai bila sekolah mampu menerapkan manajemen persekolahan yang efektif. Dalam pengantar bukunya "Manajemen Pendidikan Nasional," Tilaar mengungkapkan bahwa krisis pendidikan yang dihadapi oleh Bangsa Indonesia dewasa ini boleh dikatakan berkisar pada krisis manajemen. Oleh karena itu, untuk memperbaikinya pun haruslah dimulai dari manajemen itu sendiri (Tilaar 2003).

Kelemahan aspek manajemen merupakan persoalan klasik yang sering melanda lembaga-lembaga pendidikan Islam. Pendidikan Islam itu sendiri menurut Arif adalah pendidikan yang berdasarkan ajaran Islam atau tuntutan agama Islam dalam usaha membina dan membentuk pribadi muslim yang bertakwa kepada Allah Swt. cinta kasih kepada orang tuanya dan sesama hidupnya dan juga tanah airnya sebagai karunia yang diberikan oleh Allah Swt. Berdasarkan hal ini, maka tugas dan fungsi yang perlu diemban oleh pendidikan Islam adalah pendidikan manusia seutuhnya dan berlangsung sepanjang hayat (Arifuddin, 2008).

Dalam pendidikan Islam dikenal juga manajemen pendidikan Islam. Secara umum, manajemen pendidikan Islam memiliki banyak kesamaan dengan manajemen pendidikan secara umum, namun ada perbedaan dalam beberapa karakter. Diantara karakteristik yang membedakan teori manajemen dalam Islam dengan teori lain adalah fokus dan konsen teori Islam terhadap segala variabel yang berpengaruh (influence) terhadap aktivitas manajemen dalam dan di luar organisasi (perusahaan, negara), dan hubungan perilaku individu terhadap faktor-faktor social yang berpengaruh. Teori Islam memberikan injeksi moral dalam manajemen, yakni mengatur bagaimana seharusnya individu berprilaku. 
Tidak ada manajemen dalam Islam kecuali ada nilai atau etika yang melingkupinya, sebagaimana tidak mungkin membangun masyarakat Muslim tanpa didasari dengan akhlak.

\section{5) Manajemen Pendidikan Islam}

Menurut Septuri dalam tulisannya "Konsep Manajemen Pendidikan Islam: Sebuah Analisis Aspek Ontologi. Epistemologi, dan Aksiologi Konsep Manajemen Pendidikan Islam" mengatakan bahwa manajemen pendidikan Islam itu adalah suatu proses (Planning, Organizing, actuating, dan controling) pemanfaatan yang Islami seluruh potensi yang ada ( manusia atau bukan manusia, diri sendiri dan orang lain secara totalitas dalam aktivitas (upaya, lembaga, serta produk) pendidikan Islam, dimulai dari niat secara Islami dan untuk mencapai tujuan yang Islami”.

Berkaitan dengan hakikat dan cirri-ciri manajemen Islami. Effendy menjelaskan ada enam ciri sebagai berikut:

a) Manajemen berdasarkan akhlak yang luhur (akblakul karimah)

b) Manajemen terbuka. Artinya pengolaan yang sehat, dan terbuka (open minded) atau tranparansi. Karena jabatan sebagai pimpinan atau manajer adalah amanah yang harus dipelihara dengan baik dan penuh keadilan

c) Manajemen yang demokratis. Konsekuensi dari sikap terbuka dalam manajemen, maka pengambilan keputusan atas musyawarah untuk kebaikan organisasi. Semakin tinggi keterlibatan anggota dalam pengambilan keputusan, maka mereka semakin berdaya dalam menjalankan pekerjaannya dan mendorong munculnya kepuasan kerja dengan dibarengi imbalan yang sesuai dengan kebutuhan hidup, kemampuan organisasi dan ketentuan yang berlaku.

d) Manajemen berdasarkan ilmiah. Dengan mengamalkan prinsip pengetahuan tidak dikerjakan secara membabi buta. Artinya pimpinan dan manajer haruslah orang yang berilmu pengetahuan karena dia yang akan merencanakan, mengarahkan, mengambil keputusan dan mengawasi pekerjaan, tentu memerlukan ilmu penegtahuan yang luas tentang organisasi, manajemen dan bidang pekerjaannya.

e) Manajemen berdasarkan tolong menolong (ta'awun). Prinsip tolong menolong atau kerjasama adalah mengamalkan sunnatullah dalam menjalankan hidupnya sebagai mahkluk sosial yang diciptakan Allah, dan hal ini sejalan dengan fitrah penciptaan manusia.

f) Manajemen berdasarkan perdamaian.

Tujuan manajemen pendidikan Islam adalah agar segenap sumber, peralatan ataupun sarana yang ada dalam suatu organisasi tersebut dapat digerakkan sedemikian rupa sehingga dapat menghindarkan sampai tingkat seminimal mungkin segenap pemborosan waktu, tenaga, materil, dan uang guna 
mencapai tujuan organisasi yang telah ditetapkan terlebih dahulu (Muhaimin, dkk. , 2010).

Dengan demikian, terdapat terdapat tiga fokus untuk mengartikan manajemen, yaitu:

a) Manajemen sebagai suatu kemampuan atau keahlian yang selanjutnya menjadi cikal bakal manajemen sebagai satu profesi.

b) Manajemen sebagai proses, yaitu menentukan langkah yang sistematis dan terpadu sebagai aktivitas manajemen.

c) Manajemen sebagai seni yang tercermin dari perbedaan gaya (style) seseorang dalam menggunakan atau memberdayakan orang lain untuk mencapai tujuan (Tim Dosen Administrasi Pendidikan UPI, 2015).

Pada era reformasi ini, dimana kesadaran masyarakat tentang pentingnya pendidikan telah meningkat, melahirkan tuntutan masyarakat akan pendidikan yang bermutu. mengemukakan paradigma baru mutu pendidikan, yaitu ; pertama bahwa pendidikan dan pelatihan yang bermutu adalah pendidikan yang dibutuhkan oleh rakyat banyak; dan kedua bahwa pendidikan yang bermutu merupakan kebutuhan rakyat banyak, dan oleh karenanya partisipasi keluarga dan masyarakat dalam penyelenggaraan, investasi, dan evaluasi pendidikan harus semakin ditingkatkan. (Tilaar.2000)

\section{6) Prinsip-prinsip Manajemen Islam}

Dalam pendidikan Islam dikenal juga manajemen Pendidikan Islam. Secara umum, manajemen pendidikan Islam memiliki banyak kesamaan dengan manajemen pendidikan secara umum, namun ada perbedaan dalam beberapa karakter. Diantara karakteristik yang membedakan teori manajemen dalam Islam dengan teori lain adalah fokus dan konsen teori Islam terhadap segala variabel yang berpengaruh (influence) terhadap aktivitas manajemen dalam dan di luar organisasi (perusahaan, negara), dan hubungan perilaku individu terhadap faktor-faktor social yang berpengaruh. Teori Islam memberikan injeksi moral dalam manajemen, yakni mengatur bagaimana seharusnya individu berprilaku. Tidak ada manajemen dalam Islam kecuali ada nilai atau etika yang melingkupinya, sebagaimana tidak mungkinmembangun masyarakat Muslim tanpa didasari dengan akhlak.

\section{7) Kurikulum Pendidikan}

Menurut Nurgiantoro, bahwa kurikulum mempunyai fungsi tiga hal. Pertama, fungsi kurikulum bagi sekolah terdiri dari alat untuk mencapai tujuan pendidikan yang diinginkan. Kurikulum juga dapat dijadikan pedoman untuk mengatur kegiatan-kegiatan pendidikan yang dilaksanakan di sekolah.Misalnya, bidang studi, alokasi waktu, pokok bahasan, serta termasuk strategi pembelajarannya (Nurgiantoro 1988).

Masih mengenai fungsi kurikulum, pendapat yang hampir sama dengan Nurgiantoro dilontarkan oleh Hendyat Soetopo menurutnya bahwa fungsi 
kurikulum itu sebagai pedoman dalam mengajar kegiatan pendidikan pada suatu sekolah. Sebagai suatu alat atau sarana yang berfungsi untuk mencapai tujuantujuan pendidikan, jenis-jenis program apa yang diselenggarakan di sekolah tersebut. Hal ini berarti bahwa fungsi kurikulum menyangkut setiap jenis program, pengoprasionalan atau pelaku yang bertanggung jawab, serta media atau fasilitas yang mendukungnya (Soetopo, 1986).

\section{8) Model Pengembangan Kurikulum}

Dalam pengembangan kurikulum ada beberapa model yang digunakan antara lain : Model Administrative, Model Akar Rumput (grass roots), Model Demonstrasi, model The Demonstration Model, Interpersonal Relation Model, The computer based model, The Systematics Action-Research Model, dan model Emerging Technical Models.

\section{Metode Penelitian}

Sesuai dengan karakteristik permasalahan yang akan dibahas yaitu Arah Kebijakan Pengembangan Keilmuan Program Studi Manajemen Pendidikan Islam ditijau dari Futurologi Pendidikan dan Pengembangan Kurikulum, maka jenis penelitian ini adalah penelitian kualitatif, dengan analisis deskriptif kualitatif. Dengan demikian sebagaimana ditandaskan oleh Amirul Hadi dan Haryono bahwa penelitian ini adalah "Penelitian Lapangan (field resesrch) yang bersifat Deskritif yang menggunakan pendekatan Kualitatif yaitu uraian naratif mengenai suatu proses tingkah laku subjek sesuai dengan masalah yang diteliti" (Hadi dan Haryono, 1998). Sedangkan Bodgan dan Taylor mendefinisikan metodologi kualitatif sebagai prosedur penelitian yang menghasilkan data deskriptif kualitatif berupa kata-kata tertulis atau lisan dari orang-orang dan perilaku yang diamati (Moleong, 2002). Subyek Penelitian disini adalah arah pengembangan keilmuan program studi manajemen Pendidikan Islam. Objek penelitian yang digunakan oleh peneliti adalah Pimpinan IAIN Curup, Ketua Jurusan Tarbiyah, Sekretaris Jurusan Tarbiyah, alumni dan pengguna lulusan dan pemerintah daerah.

\section{Hasil Penelitian}

\section{1) Profil Program Studi Manajemen Pendidikan Islam}

Sekolah Tinggi Agama Islam (STAIN) Curup merupakan salah satu Perguruan Tinggi Islam Negeri yang berada di Provinsi Bengkulu dan satusatunya berada di kota Curup Kabupaten Rejang Lebong. Setelah berjalan selama hampir lebih kurang selama 20 tahun STAIN Curup sekarang sedang berbenah setelah diterbitkannya Peraturan Presiden Nomor 24 Tahun 2018 tentang Perubahan STAIN Curup menjadi Institut Agama Islam Negeri (IAIN) Curup. Dengan perubahan tersebut diharapkan sebagai wahana untuk mengembangkan inovasi edukatif yang mendorong pembentukan karakter bangsa yang positif, dan menjadi inspirasi bagi masyarakat global untuk selalu menjunjung tinggi profesionalisme dan bermartabat. Selain itu, kampus ini 
diharapkan dapat menghasilkan sumber daya manusia yang mempunyai kompetensi sesuai dengan kebutuhan, dan mempunyai wawasan kebangsaan yang kuat, mandiri, terbuka, unggul, dan progresif (Keputusan Presiden RI, Nomor 50 tahun 2018).

Program Studi Manajemen Pendidikan Islam merupakan program studi baru pada IAIN Curup bernaung di bawah Jurusan Tarbiyah. Pendirian Prodi Manajemen Pendidikan Islam berdasarkan Surat Keputusan Direktur Jenderal Pendidikan Islam Kementerian Agama Nomor : 827 Tahun 2012 tertanggal 2 Juli 2012. Gelar Akademik yang diberikan kepada sarjana lulusan Program Studi Manajemen Pendidikan Islam adalah Sarjana Pendidikan (S.Pd). Adapun akreditasi dari BAN-PT adalah C. Sesuai dengan SK BAN-PT No. 252/SK/BAN-PT/Ak-XVI/S/XII/2013. Saat ini sedang mengajukan akreditasi baru ke BAN-PT.

Program Studi Manajemen Pendidikan Islam mempersiapkan peserta didik menjadi sarjana muslim, pendidik yang memiliki keahlian dibidang pendidikan sebagai tenaga pendidik dan tenaga kependidikan dan segaligus Manajemen Pendidikan Islam beserta teori-teori pengembangan akuntabilitas pelaksanaan proses pendidikan dan pengajaran, serta memiliki kemampuan melaksanakan proses pembelajaran dalam kelompok mata pelajaran ilmu-ilmu sosial, dan mengintegrasikan sains dan agama, penguatan dimensi etik, kemanusiaan dan keIndonesiaan.

Para lulusan Program studi MPI dipersiapkan untuk memiliki potensi ganda yaitu profesi tenaga kependidikan yang memiliki keahlian dibidang tugasnya dalam pengelolaan pendidikan, dan peminatan yang menyertai keahlian utama sebagai pengembang sumber belajar pendidikan. Mereka disiapkan untuk memiliki kemampuan sebagai tenaga kependidikan yang profesional, sekaligus kemampuan mengelola sebagai lembaga pendidikan, penelitian dalam kerangka pengembangan pendidik, seiring tuntunan masyarakat global.

\section{2) Profil Lulusan Program Studi Manajemen Pendidikan Islam Main Profile (Profil Utama)}

Tenaga Kependidikan (pada lembaga pendidikan Islam dan instansi yang menangani pendidikan). Mata kuliah yang diberikan kepada diantaranya : BK, SPI, Tafsir Tarbawi, Hadis Tarbawi, Fiqih, Filsafat Pendidikan Islam, Ilmu Pendidikan Islam, Manajemen Pendidikan Islam, Psikologi Pendidikan, Statistik Pendidikan, Evaluasi Pendidikan, Perilaku dan Budaya Organisasi, Pengantar Ilmu Manajemen, Tata Laksana Manajemen Pendidikan, Manajemen Kurikulum dan Program Pendidikan, Manajemen Perkantoran dan Kearsipan, Tafsir AyatAyat Manajemen, Manajemen SDM Pendidikan, Manajemen Pemasaran Jasa Pendidikan dan Public Relation, Manajemen Pembiayaan Pendidikan, Manajemen Peserta Didik, Manajemen Sekolah dan Madrasah, Manajemen Pesantren dan Pendidikan Non Formal, Manajemen Sarana dan Prasarana 
Pendidikan, Sistem Penjaminan Mutu Pendidikan, Microleading, Ekonomi dan Kewirausahaan Pendidikan, Manajemen Pendidikan Anti Korupsi

\section{Supplementary Profiles (Profil Pendukung)}

a) Pengelola Lembaga Pendidikan (madrasah, sekolah, ponpes, majelis taklim, diniyah, lembaga kursus, balai pendidikan dan pelatihan, kelompok belajar, dan pusat kegiatan masyarakat). Mata kuliah yang diberikan untuk mendukung kemampuan ini adalah : Profesi Kependidikan, Perencanaan Pendidikan, Manajemen Mutu Pendidikan, Akuntansi Manajemen, Leadership, Manajemen PT, Manajemen Konflik, Sosiologi Pendidikan

b) Peneliti Manajemen Pendidikan. Untuk menjadi seorang peneliti mata kuliah yang diberikan adalah Metodologi Penelitian Manajemen Pendidikan, Manajemen Pendidikan dan Pelatihan, Politik dan Kebijakan Pendidikan, dan Pendidikan Multikultural

c) Perencana dan Pengembang Sumber Belajar. Untuk menjadi seorang perancang dan pengembang sumber belajar, maka mata kuliah yang diberikan sebagai berikut : IT, SIM dan Komunikasi Pendidikan, Aplikasi Komputer Manajemen, Manajemen Pusat Sumber Belajar, Manajemen Laboratorium Pendidikan, dan Manajemen Perpustakaan.

\section{Peluang Kerja (Job Opportunity)}

Education Administrator (Administrasi Pendidikan)

a) Lingkungan Kementeri Agama Pusat, Provinsi, Kabupaten/Kota dan Kecamatan

b) Perguruan Tinggi (PTAIN dan PTN)

c) Madrasah dan Sekolah

d) Kementerian Pendidikan dan Kebudayaan, Dinas Pendidikan Provinsi, Kabupaten/Kota

e) Balai Litbang dan Diklat di berbagai Kementerian

f) Tenaga Perpustakaan di PT Negeri, Madrasah dan Sekolah

Supplementary Profiles

a) Peneliti Pendidikan

b) Pengelola Lembaga Pendidikan (Madrasah, Sekolah, Ponpes, Lembaga Kursus, Balai Diklat, Majelis Taklim, Diniyah Takmiliyah, PKM)

c) Konsultan Manajemen Pendidikan

d) Wirausaha

e) Kuliah S 2 di Perguruan Tinggi

\section{3) Kurikulum Prodi Manajemen Pendidikan Islam}

Kurikulum Program Studi Manajemen Pendidikan Islam disusun sesuai yang diamanatkan : 
a) Undang Undang Nomor 20 Tahun 2003 tentang Sistem Pendidikan Nasional

b) Undang-Undang Nomor 12 Tahun 2012 tentang Pendidikan Tinggi

c) Peraturan Presiden Republik Indonesia Nomor 8 Tahun 2013 tentang Kerangka Kualifikasi Nasional Indonesia (KKNI)

d) Peraturan Menteri Riset, Teknologi dan Pendidikan Tinggi Nomor 44 Tahun 2015 tentang Standar Nasional Pendidikan Tinggi (SNPT).

\section{4) Komposisi Kurikulum dan Beban Studi}

\begin{tabular}{|c|c|c|c|}
\hline NO. & $\begin{array}{c}\text { JENIS MATA } \\
\text { KULIAH }\end{array}$ & $\begin{array}{c}\text { SKS YANG } \\
\text { DITAWARAN }\end{array}$ & $\begin{array}{c}\text { SKS WAJIB } \\
\text { DIAMBIL }\end{array}$ \\
\hline $\mathbf{1} \mathbf{1}$ & $(2)$ & $(3)$ & $(4)$ \\
\hline $\mathbf{1}$ & $\begin{array}{c}\text { Nasional dan Ke-STAIN- } \\
\text { an }\end{array}$ & 22 & 22 \\
\hline $\mathbf{2}$ & Jurusan & 28 & 28 \\
\hline $\mathbf{3}$ & Program Studi (Wajib) & 89 & 89 \\
\hline $\mathbf{4}$ & Program Studi (Pilihan)* & 18 & 9 \\
\hline & JUMLAH : & 157 & 148 \\
\hline
\end{tabular}

\section{5) Pengetahuan dan Pemahaman Seluk Beluk Program Studi MPI}

Hasil wawancara dengan berbagai pihak diperoleh data-data sebagai berikut :

Pertanyaan yang diajukan adalah apakah Bapak mengetahui visi, misi dan tujuan Prodi MPI IAIN Curup. Ketua Jurusan Tarbiyah menjawab :

Tentu saya mengetahui visi, misi dan tujuan program studi MPI, karena saya terlibat dalam perumusan tersebut. Menurut saya visi dan misi serta tujuan program studi MPI sudah baik untuk menyongsong masa depan. Berkaitan dengan itu, yang dibutuhkan adalah bagaimana kesiapan sumber daya yang ada didalammnya menjewantahkan visi, misi dan tujuan yang telah dirumuskan tersebut (Hasil wawancara hari Senin, 10 September 2018 ).

Dengan nada yang sama dikemukakan pula oleh Sekretaris Jurusan Tarbiyah, ia mengatakan bahwa :

Visi, misi, dan tujuan Program Studi MPI pada intinya adalah menjadikan Program Studi MPI sebagai pusat sumber belajar bidang manajemen pendidikan Islam berbasis ICT di Wilayah Sumatera tahun 2028 dengan menyelenggarakan pendidikan dan pengajaran yang bermutu untuk menghasilkan lulusan Manajemen Pendidikan Islam yang berakhlak mulia, kompeten, profesional, kritis, dan berwawasan luas 
dengan menjalin kerjasama dan menumbuhkan pengabdian kepada masyarakat. Menurut saya masih relevan, hanya saja pada sasaran dan profil yang perlu perbaikan (Hasil wawancara hari Senin, 10 September 2018 ).

Pertanyaan serupa juga ditanyakan kepada dosen prodi MPI diantaranya bapak Syaiful Bahri dan bapak Irwan Fathurrochman. Bapak Syaiful Bahri menjawab bahwa :

Saya mengetahui dan memahami visi, misi dan tujuan Program studi MPI, karena sudah seharusnya dan selayaknya semua dosen yang mengajar di program studi MPI mengetahui dan memahaminya. Visi, misi dan tujuan prodi MPI akan menjiwai kedalam seluruh aktivitas akademik dan program MPI termasuk program mengajar dosen. Dengan demikian diharapakan visi, misi dan tujuan Program Studi MPI akan terwujud pada tahun 2028 mendatang. Visi, misi dan tujuan program studi MPI menurut hemat saya masih relevan untuk saat ini (Hasil wawancara hari Senin, 10 September 2018 ).

Mengetahui dan memahami visi, misi dan tujuan program studi MPI bagi saya sesuatu keharusan, sebab dosen adalah salah satu pilar dalam system secara khusus di program studi MPI dan di IAIN Curup secara umum. Jika semua system bergerak dengan simultan maka akan visi, misi, dan tujuan yang hendak dicapai oleh program studi MPI akan mudah terwujud. Misalnya prodi memiliki tujuan menghasilkan lulusan yang beriman dan bertakwa kepada Allah SWT. professional, kritis dan berwawasan luas. Mampu melaksanakan penelitian dan pengabdian masyarakat dalam bidang Manajemen Pendidikan Islam pada tingkat regional dan nasional serta menjalin kerjasama dengan berbagai pihak dan mengembangkan sumber belajar yang berbasis ICT. Jika dosen ikut serta didalam pencapaiaan tujuan tersebut, maka akan terwujud. Menurut saya masih relevan untuk diterapkan pada saat ini (Hasil wawancara hari Senin, 10 September 2018 ).

Dalam keputusan Perkumpulan Program Studi Manajemen Pendidikan Islam (PPMPI) menjelaskan tentang kaedah dalam menetapkan standar kompetensi lulusan sebagai berikut :

Pertama, Keputusan Perkumpulan Program Studi Manajemen Pendidikan Islam (PPMPI) Tentang Standar Kompetensi Lulusan dan Capaian Pembelajaran Lulusan Program Studi jenjang Sarjana pada perguruan tinggi keagamaan Islam dan Fakultas Agama Islam Pada Perguruan Tinggi, dan nama-nama mata kuliah wajib pada Program Studi Manajemen Pendidikan Islam. Kedua, Menetapkan Standar Kompetensi Lulusan dan Capaian Pembelajaran Lulusan Program Studi Manajemen Pendidikan Islam Jenjang Sarjana pada Perguruan Tinggi Keagamaan 
Islam dan Fakultas Agama Islam pada Perguruan Tinggi sebagaimana tercantum dalam Keputusan Direktur Jenderal Pendidikan Islam Nomor 2500 Tahun 2018 adalah bagian tidak terpisahkan dari Keputusan ini. Ketiga, PPMPI dalam menetapkan Standar Kompetensi Lulusan mengacu kepada Standar Kompetensi Lulusan sebagaimana dimaksud dalam Diktum kesatu, dan merupakan kriteria minimal tentang kualifikasi kemampuan lulusan yang mencakup sikap, pengetahuan dan keterampilan yang dinyatakan dalam rumusan capaian pembelajaran lulusan.

Empat, PPMPI dalam menetapkan Capaian Pembelajaran Lulusan mengacu kepada Capaian Pembelajaran Lulusan sebagaimana dimaksud dalam Diktum kesatu, dan merupakan kriteria minimal tentang rumusan operasional standar kompetensi lulusan.

Dalam penyusunan nama mata kuliah Perkumpulan Program Studi Manajemen Pendidikan Islam (PPMPI) telah menetapkan beberapa mata kuliah yang wajib ada sebagai berikut :

Perkumpulan Program Studi Manajemen Pendidikan Islam (PPMPI) menetapkan nama mata kuliah yang wajib ada di program studi manajemen pendidikan Islam sebagai upaya standardisasi Program Studi, dan merupakan standar minimal mata kuliah. Sebagaimana dalam Peraturan Menteri Riset, Teknologi dan Pendidikan Tinggi Nomor 44 Tahun 2015 tentang Standar Nasional Pendidikan Tinggi, Prodi MPI amenempouh minimal SKS sebanyak 144. PPMPI menetapkan 32 jumlah matakuliah beserta SKS minimalnya sebanyak 82 SKS, sedangkan 18 SKS lainnya diserahkan kepada prodi masing-masing untuk menambahkan sks, bisa pada mata kuliah yang telah ada atau dengan menambah mata kuliah lain sesuai dengan ke khasan wilayah prodi masing-masing. Masih ada 44 SKS diisi oleh mata kuliah Nasional, Institusi/lembaga dan Fakultas (Hasil Keputusan Kurikulum Prodi MPI Malang 13-15 September 2018 Nomor: 05/PPMPI/IX/2018).

\section{Kesimpulan}

Arah pengembangan keilmuan Program Studi MPI Jurusan Tarbiyah IAIN Curup mengacu pada filosofi teo-antrokosmosentris sistemik. Paradigma teo-antrokosmosentris sistemik adalah kerja pengetahuan yang didasarkan pada upaya mempertalikan, mengingkat, dan mengakomodasi ilmu-ilmu keislaman, ilmu budaya-sosial dan ilmu pengetahuan. Menjadikan tiga rumpun ini sebagai mata rantai yang tak boleh putus yang artinya melakukan penggabungan berbagai unsur pengetahuan yang bersumber dari ke-tuhanan, dan kemanusiaan. Ke-tuhanan terdiri dari ilmu-ilmu keislaman termasuk manajemen Islam. Ke-manusiaan terdiri dari ilmu-ilmu sosiologi, budaya, komunikasi dan ilmu yang berkembang dan tumbuh pada kearifan lokal. Dalam kontek keahlian 
program studi MPI pengembangan keilmuan diarahkan kepada kemampuan penataan, pengelolaan, dan pengembangan dunia pendidikan secara luas dengan bersandar pada nilai-nilai keluhuran agama Islam. Islam adalah agama rahmatan lil'alamin yang dapat menjadi solusi dalam mengentaskan problematika kehiduapan masyarakat dewasa ini. Islam itu adalah suatu pimpinan jasmani dan rohani yang menuju kepada kesempurnaan dan lengkapnya sifat-sifat kemanusiaan dengan arti yang sesungguhnya. Tujuan hidup manusia mengacu pada tatanan hidup yang seimbang, dunia dan akhirat, jasmani dan rohani. Kecerdasan otak dengan keimanan kepada Allah, ketajaman akal dengan keahlian untuk bekerja. Hal inilah yang sesuai dengan prinsip-prinsip ajaran Islam.

\section{Daftar Pustaka}

Abd. Sani, 2013, Inovasi Pembelajaran, (Jakarta: Bumi Aksara)

Abdul Ghofir, 1993, Pengenalan Kurikulum Madrasah, (Solo: CV, Ramadhani)

Agus Zaenul Fitri, Manajemen Kurikulum Pendidikan Islam dari Normatif-Filosofis ke Praktis, (Bandung: Alfabeta, 2013

Alvin Toffler. 1992. Gelombang Ketiga (bagian kedua). Alih bahasa Sri Koesdiyantinah (Jakarta: Penerbit Pantja Simpati)

Alvin Toffler. 1992. Kejutan Masa Depan. Alih bahasa Sri Koesdiyantinah Jakarta: Penerbit Pantja Simpati).

Amin, Muhammad, Arsil, Irwan Fathurrochman, Syaiful Bahri, Sri Rahmaningsih. (2019). Manajemen Mutu Pendidikan Pada Perguruan Tinggi. Rejang Lebong; LP2 IAIN Curup.

Amin, Muhammad, Sandya Suci Larasati, and Irwan Fathurrochman. "Implementasi Manajemen Kesiswaan Dalam Meningkatkan Prestasi Non Akademik Di Smp Kreatif "Aisyiyah Rejang Lebong." Jurnal Literasiologi 1, no. 1 (2018): 19-19.

Amirul Hadi dan Haryono,1998, Metodologi Penelitian Pendidikan,(Jakarta: Pustaka setia)

Amirul Hadidan Haryono,(1998), Metodologi Penelitian Pendidikan, Jakarta : Pustakasetia

Arif, Arifuddin, 2008,Pengantar Ilmu Pendidikan Islam. (Jakarta: Kultura)

Armahedi Mazhar, 1983, Integralisme Sebuah Rekonstruksi Filsafat Islam, (Bandung: Penerbit Pustaka)

Asep Herry Hernawan dkk., 2002, Modul 10, Pengembangan kurikulum dan pembelajaran: Perumusan Tujuan Pembelajaran, (Jakarta: Penerbit UT)

Azyumardi Azra, 1999. Esei-Esei Interlektual Muslim Dan Pendidikan Islam, (Jakarta: Logos Wacana Ilmu), h. 31

Binti Maunah, Pengembangan Kurikulum Berbasis Kompetensi: Implementasi pada Tingkat Pendidikan Dasar (SD/MI)

Buchori, M. 2001. Pendidikan Antisipatoris. (Yogyakarta: Penerbit Kanisius) 
Burhan Nurgiyantoro, Dasar-Dasar Pengembangan Kurikulum Sekolah: Sebuah Pengantar Teoritis dan Pelaksanaan, (Yogyakarta: BPFG, 1988)

Dakir. 2004. Perencanan dan Pengembangan Kurikulum. Jakarta. Rineka Cipta.

Deddy Mulyana, Metodologi Penelitian Kualitatif, (Jakarta: RemajaRodaskarya)

Ella Yulaelawati 2003, Kurikulum dan Pembelajaran Filosofi teori dan aplikasi, Bandung: Pakar Raya).

Fathurrochman, Irwan, Eka Apriani, and Sri Rahmaningsih. "Analisis Rencana Pelaksanaan Program Pendukung Surat Keterangan Pendamping Ijazah (SKPI) Di STAIN Curup." ITQAN: Jurnal Ilmu-Ilmu Kependidikan 9, no. 2 (2018): 81-96.

Fathurrochman, Irwan. "Facebook Sebagai Media Pembelajaran Dalam Meningkatkan Motivasi Belajar." ITQAN: Jurnal Ilmu-Ilmu Kependidikan 9, no. 1 (2018): 1-28.

Fathurrochman, Irwan. "Implementasi Manajemen Kurikulum Dalam Upaya Meningkatkan Mutu Santri Pondok Pesantren Hidayatullah/Panti Asuhan Anak Soleh Curup." TADBIR: Jurnal Studi Manajemen Pendidikan 1, no. 1 (2017): 85-104.

Fathurrochman, Irwan. "Pengembangan Kompetensi Pegawai Aparatur Sipil Negara (ASN) Sekolah Tinggi Agama Islam Negeri (STAIN) Curup.” Manajer Pendidikan 11, no. 21 (2017): 120-29.

Hasan Langgulung, 1986, Manusia Dan Pendidikan, Suatu Analisa Psikologi Dan Pendidikan (Jakarta: PT Alhusna Zikra)

Hasan Langgulung, 2000. Asas-Asa Pendidikan Islam (Jakarta: Al-Husna Zikra)

Hasan Alwi, dkk., 2003, Kamus Besar Bahasa Indonesia, (Jakarta: Balai Pustaka)

Ibn Kathir 1988, Tafsir al-Qur'an al-'Azim, j. 1, Husayn Ibrahim Zahran (ed.).Beirut: Dar al-Fikr)

Iin Purnamasari, Rekonstruksionisme-Futuristik Dalam Pendidikan Di Indonesia, Jurnal Ilmiah CIVIS, Volume V, No 2, Juli 2015

Imron, Ali. 2012. Kebijakan Pendidikan di Indonesia: Proses, Produk \& Masa Depannya. (Jakarta: PT Bumi Aksara)

Jalaluddin,2002, Filsafat Pendidikan, (Jakarta: Gaya Media Pratama)

Jhon M Echols dan Hasan Shadly, 2000, Paradigma Pendidikan Masa Depan, (Yogyakarta: Bigraf)

Lexy J. Moleong, 2006, Metodologi Penelitian kualitatif, (Bandung: Remaja Rosdakarya)

Miles,M.B, dan Huberman, M, 1992, Qualitative Data Analisi A sour cebook of New Method,(Baverly Hills: Sage Publication)

Miles,M.B, danHuberman, 1992 M,Qualitative Data Analisi A sour cebook of New Method, Baverly Hills: Sage Publication

Morin, E. 2005. Tujuh Materi Penting bagi Dunia Pendidikan. (Yogyakarta: Kanisius) 
Muhadjir, N. 2000. Kebijakan dan Perencanaan Sosial: Pengembangan Sumber Daya Manusia, Telaah Cross Discipline. (Yogyakarta: Rake Sarasin)

Muhaimin, 1991, Konsep Pendidikan Islam, (Solo: CV.Ramadhani)

Muhammad Ilyasin dan Nanik Nurhayati, 2012, Manajemen Pendidikan Islam, (Malang: AM. Publishing)

Muhammad Zaini, 2009, Pengembangan Kurikulum: Konsep Implementasi dan Inovasi, (Yogyakarta: Teras)

Mulyasa, E. 2006. Kurikulum yang Disempurnakan. Bandung. Remaja Rosdakarya.

Nana Sudjana, 2005, Pembinaan dan Pengembangan Kurikulum di Sekolah, Sinar Baru Algensindo

Nana Syaodih Sukmadinata,2013, Pengembangan Kurikulum Teori dan Praktek, (Bandung: Remaja Rosdakarya)

Nasution,1999, Asas-asas Kurikulum, (Jakarta: Bumi Aksara)

Nawawi, H. 2003. Manajemen Strategik Organisasi Non Profit Bidang Pemerintahan Dengan Ilustrasi di Bidang Pendidikan. (Yogyakarta: Gadjah Mada University Press).

Nurgiantoro 1988, Dasar-dasar Pengembangan Kurikulum Sekolah, (Yogyakarta: BPFE), Hendyat Soetopo, 1986, Pembinaan dan pengembangan kurikulum, (Jakarta: Bina Aksara)

Nuzuar, Irwan Fathurrochman, Muhammad Amin. (2017). Manajemen dan Metodologi Pendidikan Agama Islam. Rejang Lebong; LP2 IAIN Curup.

Oemar Hamalik,1993, Pengambangan Kurikulum Lembaga Pendidikan dan Pelatihan, (Bandung: PT. Tri Genda Karya)

Parker, Jeanette Plauche 2004, Developing Creative Leadership.(Portsmouth: Teacher Ideas Press)

Ramayulis, 2008, Ilmu Pendidikan Islam. (Jakarta: kalam Mulia).

Ristianti, Dina Hajja, Sudarwan Danim, Hadi Winarto, and I Wayan Dharmayana. "The Development Of Group Counselling Assessment Instruments.” International Journal of Scientific \& Technology Research 8, no. 10 (2019): 267-72. http://www.ijstr.org/paperreferences.php?ref=IJSTR-1019-23814.

Ristianti, Dina Hajja. "Pengaruh Pemahaman Mahasiswa Terhadap Program Studi Dengan Ketahanan Belajar Mahasiswa (Studi Terhadap Mahasiswa Tahun Akademik 2014/2015 Jurusan Tarbiyah STAIN CURUP)." PROCEEDING IAIN Batusangkar 1, no. 1 (2017): 199-212.

Rusman, 2009, Manajemen Kurikulum, (Jakarta: Raja Grafindo Persada)

Safruddin Nurdin, 2002, Guru Profesional dan Implementasi Kurikulum,(Jakarta: Ciputat Pers)

Shane, H. G. 2002, Arti Pendidikan Bagi Masa Depan (EdisiKetiga). (Jakarta: PT. RajaGrafindo Persada).

Sintia Catur Sutantri, Hubungan Antara Teori Sistem Dan Futurologi Januari 04, 2017 
Sudjana, D., 2004 Manajemen Program Pendidikan: Untuk Pendidikan Nonformal dan Pengembangan Sumber Daya Manusia. (Bandung: Falah Production).

Sugiatno, Sugiatno. "Desain Kelembagaan Satuan Pengawas Internal (SPI) di STAIN Curup (Sebuah Penawaran Desain SPI Untuk Efektivitas Dan Efisien Pengelolaan Keuangan, Kinerja Pegawai Dan Aset Negara)." Tadbir: Jurnal Studi Manajemen Pendidikan 2, no. 1 (2018): 89-106.

Suharsimi Arikunto,1998, Prosedur Penelitian Suatu Pendekatan Praktek, Jakarta : Rineka Cipta

Sukmadinata, Nana Syaodih. 2005. Pengembangan Kurikulum Teori dan Praktik. Bandung. Remaja Rosdakarya. cet. ke-7.

TarsitoWinarto,1993, Pengantar Penelitian, Bandung : Mizan

Tilaar 2003,Manajemen Pendidikan Nasional. (Bandung: Remaja Rosdakarya), h. xii Tilaar. H. A. R. 2000. Paradigma Baru Pendidikan Nasional. (Jakarta: PT. Rineka)

Tim Dosen Administrasi Pendidikan UPI, Manajemen Pendidikan, (Bandung: Alfabeta)

Tim Pengembang MKDP Kurikulum dan Pembelajaran. 2011. Kurikulum dan Pembelajaran. Ed. 3. (Jakarta. Rajawali Pres).

Tim Penulisan, Profil STAIN Curup, LP2M STAIN Curup, 2016

Udik Budi Wibowo Artikel ini telah dimuat dalam Jurnal Manajemen Pendidikan No.02/ThIII/Oktober/2007. ISSN: 1978-1938

Undang-Undang Republik Indonesia Nomor 20 Tahun 2003 tentang Sistem Pendidikan Nasional. 2014. Jakarta: Sinar Grafika.

Usman Husaini, 2005, Metodologi Penelitian Sosial, Jakarta: PT Bumi Aksara)

Van Hoeve; Hassan Shadily.Ensiklopedia Indonesia, Jilid 7.(Jakarta: Ichtiar Baru), Dalam Wikipedia di akses tanggal 20 Agustus 2018.

Waryani Fajar Riyanto, Studi Islam Indonesia (1950-2014): Rekontruksi Sejarah Perkemnangan Studi Islam Integratif dii Program Pascasarjana Perguruan Tinggi Agama Islam (PTAI) dan AICIS. (Ponorogo: STAIN Ponorogo Press, 2014). 